\title{
Türkiye’nin Doğusunda Yer Alan Doğal Bir Meranın Toprak ve Bitki Örtüsünün Beslenme Dinamiği
}

\author{
Mehmet Arif ÖZYAZICI ${ }^{1} \&$ Abdurrahman YILDIZ \\ ${ }^{1}$ Siirt Üniversitesi, Ziraat Fakültesi, Tarla Bitkileri Bölümü, Siirt \\ $\bowtie$ : arifozyazici@siirt.edu.tr
}

Geliş (Received): 03.11.2017

Kabul (Accepted): 15.12.2017

\begin{abstract}
ÖZET: Bu araştırma; Van ili, Gürpınar ilçesi, Kırkgeçit Köyü merası topraklarının bazı fiziksel ve kimyasal özellikleri ile meradan elde edilen kaba yemlerin bazı makro besin maddesi durumunun belirlenmesi amaciyla yürütülmüştür. $\mathrm{Bu}$ amaçla 30 adet toprak ve bitki örneği alınmış; toprak örneklerinin bazı fiziksel ve kimyasal özellikleri [kum, kil, silt, toprak reaksiyonu $(\mathrm{pH})$, elektriksel iletkenlik (EC), kireç (CaCO3), organik madde] ile, hem toprak hem de bitki örneklerinin fosfor $(\mathrm{P})$, potasyum $(\mathrm{K})$, kalsiyum $(\mathrm{Ca})$ ve magnezyum $(\mathrm{Mg})$ gibi bazı makro besin maddeleri kapsamları belirlenmiştir. Araştırma sonuçlarına göre; incelenen mera topraklarının killi bünyeli, nötr karakterli olduğu ve tuzluluk probleminin bulunmadığı; mera topraklarının büyük çoğunluğunun az kireçli olduğu, organik madde ve alınabilir $\mathrm{K}$, Ca ve Mg miktarlarının yeterli, alınabilir P içeriklerinin ise yetersiz olduğu tespit edilmiştir. Meradan elde edilen kuru otun $\mathrm{P}, \mathrm{K}, \mathrm{Ca}, \mathrm{Mg}$ ve $\mathrm{K} / \mathrm{Ca}+\mathrm{Mg}$ oranlarının sırasıyla; \% $0.22-0.28, \%$ 2.35-2.70, \% 0.86-1.23, \% 0.20-0.22 ve 1.89-2.61 arasında değiştiği belirlenmiştir.
\end{abstract}

Anahtar Kelimeler: Mera, toprak analizi, makro elementler, yem kalitesi

\section{Nutrition Dynamics of Soil and Vegetation of a Natural Rangeland in the Eastern of Turkey}

ABSTRACT: This research was conducted to determine some physical and chemical properties of the rangeland soils and the nutritional status of the roughages obtained from rangeland in terms of some macro nutrient elements in Kırkgeçit Village, Gürpınar-Van Province. For this purpose, 30 soil and plant samples were taken. Some chemical and physical properties (soil texture, $\mathrm{pH}$, electrical conductivity, lime, organic matter) of soil, and some macro nutrients, such as phosphorus $(\mathrm{P})$, potassium $(\mathrm{K})$, calcium $(\mathrm{Ca})$, magnesium $(\mathrm{Mg})$, contents of the both soil and plant samples were determined. According to the results, it had been determined that soils of the rangeland area were neutral in $\mathrm{pH}$, clayey in texture and had no salinity problem. It was determined that most of the rangeland soils are less calcareous; organic matter and available $\mathrm{K}, \mathrm{Ca}$ and $\mathrm{Mg}$ contents are sufficient, and available $\mathrm{P}$ content is insufficient. The ratio of $\mathrm{P}, \mathrm{K}, \mathrm{Ca}, \mathrm{Mg}$ and $\mathrm{K} / \mathrm{Ca}+\mathrm{Mg}$ of hay obtained from rangeland were determined as $0.22-0.28$, 2.35-2.70, 0.86-1.23, 0.20-0.22\% and 1.89-2.61, respectively.

Key Words: Rangeland, soil analysis, macro elements, forage quality

\section{GíRiș}

Türkiye'de, kaliteli kaba yemin temin edildiği en önemli kaynakların başında yer alan çayır-mera alanı, Türkiye İstatistik Kurumu verilerine göre yaklaşık 14.6 milyon hektar (Anonim, 2017)'dır. Mevcut mera alanının büyük bir çoğunluğu (10.3 milyon ha) uzun ya da kısa süreli kuraklıkların hüküm sürdüğü Doğu, Orta ve Güneydoğu Anadolu Bölgesi’nde yer almaktadır (Gökkuş, 2014). Aşırı, zamansız ve bilinçsiz otlatmanın yanında iklim değişikliği, küresel ısınma ve kuraklık tehdidi gibi faktörlerin de etkisiyle ülkemiz mera alanlarında; klimaks vejetasyonun dengesinin bozulması, botanik kompozisyonda iyi cins yem bitkisi türlerinin azalması, bitki örtülerinde seyrekleşme meydana gelmesi mera alanlarının su ve toprak erozyonu riskini ciddi boyutlarda artırmıştır (Gökkuş ve Koç, 1996; Ayan ve ark., 2007; Yavuz ve ark., 2012; Ağın ve Kökten, 2013). Bu durum mera vejetasyonlarının farklılaşmasının yanı sıra, toprak yapısının bozulmasına ve toprak verimliliğinin de azalmasina neden olmaktadir.

Bitki örtülerindeki farklılıklara toprak yapısı, toprağın temel verimlilik durumu ile besin maddesi kapsamı gibi faktörlerin etkide bulunduğu dikkate alındığında; meralardaki botanik kompozisyon, yem verimi ve yem kalitesi gibi özelliklerin yanında, mera topraklarının bazı fiziksel ve kimyasal özelliklerinin de ortaya konulması, mera alanlarının uygun tekniklerle ıslah edilmesi açısından büyük önem taşımaktadır. Bu çalışmada, Türkiye'nin Doğu Anadolu Bölgesi'nde yer alan doğal bir meranın; topraklarının temel verimlilik özelliklerinin belirlenmesi ve meraların bazı makro bitki besin maddesi yönünden durumlarının toprak ve bitki analizleriyle ortaya konulması amaçlanmıştır.

\section{MATERYAL ve METOT}

Araştırma, Türkiye'nin Doğu Anadolu Bölgesi'nde yer alan, Van ili Gürpınar ilçesine bağlı, alan bakımından ilçenin en geniş meralarından biri olan Kırkgeçit Köyü merasının; toprak, topografya, bitki örtüsü ve diğer faktörler bakımından farklılıklar gösteren üç farklı "Mera Kesimi”nde (kuzey, güney ve batı yöneyleri) 01 Mayıs-24 Haziran 2015 tarihleri arasında yürütülmüştür.

Her mera kesiminde; vejetasyon, toprak ve eğim açısından yöneyi temsil edecek şekilde ölçüm alanları belirlenmiş ve bu alanların 10 farklı noktasına (vejetasyonun uyanmaya başladığı ve/veya otlatma 
tarihinden önce) 01 Mayıs 2015 tarihinde kuadratlar (50 $\mathrm{cm}$ x $50 \mathrm{~cm}$ boyutlarındaki demir kafesler) yerleştirilmiştir. Böylece, çalışmada 10 tekrarlama esas alınmak suretiyle, her mera kesimine 10'ar (tekerrür) ve toplamda ise 30 demir kafes meraya konulmuştur. Her mera kesiminde, vejetasyon ölçümleri için yerleştirilen kuadratların bulunduğu yerin $0-20 \mathrm{~cm}$ toprak derinliğinden toprak örnekleri alınmıştır. Alınan toprak örneklerinde; kum, kil, silt, pH, EC, kireç, organik madde, alınabilir $\mathrm{P}, \mathrm{K}, \mathrm{Ca}$ ve $\mathrm{Mg}$ analizleri Anonymous (1982 ve 1986) tarafindan bildirilen esaslara göre yapılmıştır.

Kuadratlar içindeki ot, toprak seviyesinden biçilmiş; biçilen otu oluşturan bitki türleri buğdaygiller, baklagiller ve diğer familya bitkileri olarak gruplara ayrılmıștır. Her mera kesimindeki 10 kuadratın her birinden biçilen ve gruplarına ayrılan ot örnekleri kurutulduktan sonra yine bitki gruplarına göre öğütülmüştür. Öğütülen örneklerin toplam $\mathrm{P}, \mathrm{K}, \mathrm{Ca}$ ve $\mathrm{Mg}$ içerikleri; NIRS (Near Infrared Reflektance Spectroscopy) analiz cihazı ile NIR (Near Infrared Analysis, Yakın Kızıl Ötesi Analizi) spektroskopik teknikle (Hoy ve ark., 2002) belirlenmiștir. Her bir mera kesimine göre, her kuadrattan elde edilen bitki grupları bazında, bitki gruplarının botanik kompozisyona katılma payı dikkate alınarak; ağırlığa göre botanik kompozisyondaki oranlarının, belirlenen $\mathrm{P}, \mathrm{K}, \mathrm{Ca}$ ve $\mathrm{Mg}$ değerleri ile çarpılması ve elde edilen rakamların toplanması sonucu, her bir kuadrattaki mera otunun ortalama $\mathrm{P}, \mathrm{K}, \mathrm{Ca}$ ve $\mathrm{Mg}$ değerleri saptanmıştır. Belirlenen $\mathrm{K}$ oranının, $\mathrm{Ca}$ ve $\mathrm{Mg}$ oranlarının toplamına bölünmesi ile $\mathrm{K} / \mathrm{Ca}+\mathrm{Mg}$ oranı belirlenmiştir.

Araştırma topraklarının fiziksel ve kimyasal özelliklerine ait veriler; sınır değerlere göre sınıflandırılmış, toprak örneklerinin dağılımı ve oranları hesaplanarak değerlendirmeler yapılmıştır. Mera kuru otunun makro element kapsamlarına ilişkin veriler, tesadüf parselleri deneme desenine göre varyans analizi
(ANOVA)'ne tabi tutulmuş (Montgomery, 2001); F testi sonuçlarına göre gruplar arasındaki farklılıklar Tukey çoklu karşılaştırma testi ile belirlenmiştir (Larsen ve Marx, 2001)

\section{BULGULAR ve TARTIŞMA \\ Mera Topraklarının Bazı Fiziksel ve Kimyasal} Özellikleri

Kırkgeçit Köyü merasının farklı kesimlerinden (yöneyler) alınan toprak örneklerinin bazı fiziksel ve kimyasal analiz sonuçlarına ilişkin en küçük, en büyük ve ortalama değerler Çizelge 1'de; mera geneli itibariyle, incelenen toprak özelliklerinin sinır değerlerine göre sinıflandırılması ise Çizelge 2'de sunulmuştur.

1. Toprak bünyesi: Toprağın kum, kil ve silt gibi parçacıkların oranından oluşan toprak bünyesi, toprağın verimlilik düzeyini belirleyen önemli fiziksel özelliklerindendir (Özyazıcı ve ark., 2016). Mera geneline göre toprakların kum, kil ve silt içerikleri sirasiyla \% 7.92-41.84, \% 45.44-59.60 ve \% 5.44-38.48 arasında değiştiği (Çizelge 1), bünye sınıfının mera yöneyleri arasında farklılık göstermediği ve incelenen mera topraklarının Anonymous (1951)'a göre yapılan sınıflandırmada bünye sınıfının kil olduğu (Çizelge 2) tespit edilmiştir. Dolayısıyla, küçük boyutlu tanelerden oluşan fraksiyonların çoğunlukta olduğu bu topraklar ince tekstürlü olarak tanımlanır. Araştırmada elde edilen bu sonuçlar, mera yöneyleri bakımından toprak bünye sınıfları arasında önemli bir farkın görülmediği şeklindeki Kılıç (2013)'ın bulguları ile uyumlu olduğu görülmüştür. Farklı mera alanlarında yapılan çalışmalarda, örneğin; Erzurum-Pasinler yöresi (Avağ, 2002), Bartın yöresi (Bolat, 2007) ve Isparta ili Sütçüler ilçesi (Babalık ve Sarıkaya, 2015) meralarında da toprakların kil içeriğinin, araştırmamız bulgularında olduğu gibi yüksek olduğu ve mera topraklarının bünye sınıfının genelde killi olduğu bildirilmiştir.

Çizelge 1. Kırkgeçit köyü merası topraklarının bazı fiziksel ve kimyasal özellikleri

\begin{tabular}{|c|c|c|c|c|c|c|c|c|c|c|c|}
\hline & \multicolumn{3}{|c|}{ Bünye (\%) } & \multirow{2}{*}{$\mathrm{pH}$} & \multirow{2}{*}{$\begin{array}{c}\mathrm{EC} \\
\left(\mathrm{dS} \mathrm{m}^{-1}\right)\end{array}$} & \multirow{2}{*}{$\begin{array}{c}\mathrm{CaCO}_{3} \\
(\%)\end{array}$} & \multirow{2}{*}{$\begin{array}{l}\mathrm{OM} \\
(\%)\end{array}$} & \multirow{2}{*}{$\begin{array}{c}\mathrm{P} \\
(\mathrm{ppm})\end{array}$} & \multirow{2}{*}{$\begin{array}{c}\mathrm{K} \\
(\mathrm{ppm})\end{array}$} & \multirow{2}{*}{$\begin{array}{c}\mathrm{Ca} \\
(\mathrm{ppm})\end{array}$} & \multirow{2}{*}{$\begin{array}{c}\mathrm{Mg} \\
(\mathrm{ppm})\end{array}$} \\
\hline & Kum & Kil & Silt & & & & & & & & \\
\hline \multicolumn{12}{|c|}{ Kuzey kesimi } \\
\hline En küçük & 7.92 & 50.16 & 5.44 & 6.94 & 0.117 & 0.1 & 3.45 & 0.011 & 313 & 4352 & 307 \\
\hline En büyük & 41.84 & 55.44 & 38.48 & 7.38 & 0.259 & 7.6 & 12.45 & 0.097 & 1092 & 12194 & 1153 \\
\hline Ortalama & 20.33 & 53.00 & 26.67 & 7.15 & 0.178 & 2.3 & 6.29 & 0.043 & 570 & 7405 & 577 \\
\hline \multicolumn{12}{|c|}{ Güney kesimi } \\
\hline En küçük & 10.40 & 45.44 & 26.48 & 7.08 & 0.149 & 0.1 & 3.21 & 0.013 & 376 & 6079 & 192 \\
\hline En büyük & 21.36 & 57.44 & 36.16 & 7.44 & 0.242 & 13.1 & 11.51 & 0.041 & 605 & 11345 & 624 \\
\hline Ortalama & 16.41 & 52.33 & 31.26 & 7.30 & 0.193 & 3.4 & 6.25 & 0.022 & 471 & 7898 & 417 \\
\hline \multicolumn{12}{|c|}{ Batı kesimi } \\
\hline En küçük & 11.12 & 53.44 & 21.44 & 6.85 & 0.099 & 0.1 & 2.76 & 0.011 & 213 & 5624 & 155 \\
\hline En büyük & 24.56 & 59.60 & 31.44 & 7.42 & 0.204 & 14.8 & 9.44 & 0.034 & 714 & 11849 & 927 \\
\hline Ortalama & 15.62 & 56.13 & 28.25 & 7.16 & 0.159 & 3.8 & 5.05 & 0.023 & 431 & 7782 & 455 \\
\hline \multicolumn{12}{|c|}{ Kırkgeçit Köyü merası geneli } \\
\hline En küçük & 7.92 & 45.44 & 5.44 & 6.85 & 0.099 & 0.1 & 2.76 & 0.011 & 213 & 4352 & 155 \\
\hline En büyük & 41.84 & 59.60 & 38.48 & 7.44 & 0.259 & 14.8 & 12.45 & 0.097 & 1092 & 12194 & 1153 \\
\hline Ortalama & 17.45 & 53.82 & 28.73 & 7.20 & 0.177 & 3.2 & 5.86 & 0.029 & 491 & 7695 & 483 \\
\hline
\end{tabular}

$\mathrm{CaCO}_{3}$ : Kalsiyum karbonat, OM: Organik madde 
2. $\boldsymbol{p H}$ : Araştırmada mera yöneyleri itibariyle toprak pH'sının 6.85-7.44 arasında değiştiği (Çizelge 1) ve incelenen mera topraklarının nötr karakterli olduğu (Çizelge 2) belirlenmiştir. pH bakımından elde edilen bulgular; Ağın ve Kökten (2013), Özaslan Parlak ve ark. (2015) ve Taşdemir (2015)'in bulgularıyla uyumlu olduğu görülmüştür. Bununla birlikte; Uslu (2005), Kahramanmaraș Türkoğlu ilçesi Araplar Köyü Yeniyapan merası topraklarının $\mathrm{pH}$ değerinin 5.28 değeriyle orta derecede asitli; Türker (2006), MersinTarsus Olukkayak Köyü Topak Ardıç mevkii merası topraklarının orta alkali karakterde; Çaçan ve Kökten
(2014), Bingöl ili Merkez ilçesi Çiçekyayla Köyü merası topraklarının hafif derecede asitli olduğunu bildirmektedirler.

3. $\boldsymbol{E C}$ : Mera topraklarının EC değeri mera yöneyleri itibariyle 0.099-0.259 $\mathrm{dS} \mathrm{m}^{-1}$ arasında değişmekte olup (Çizelge 1); mera topraklarının Türkiye'nin farklı ekolojilerinde yapılan çalışmalarda (Türker, 2006; Şengönül ve ark., 2009; Ağın ve Kökten, 2013; Çaçan ve Kökten, 2014; Özaslan Parlak ve ark., 2015) olduğu gibi tuzluluk yönünden bir sorun teşkil etmediği belirlenmiştir (Çizelge 2).

Çizelge 2. Mera topraklarının bazı fiziksel ve kimyasal özellikleri yönünden sınıflandırılması

\begin{tabular}{|c|c|c|c|c|}
\hline Toprak özelliği & Sinır değeri & Değerlendirme & Örnek sayıs1 & $\%$ \\
\hline Bünye sınıfi (Anonymous, 1951) & & Kil (C) & 30 & 100.0 \\
\hline \multirow{6}{*}{$\begin{array}{l}\mathrm{pH} \\
\text { (Ülgen ve Yurtsever, 1995) }\end{array}$} & $<4.5$ & Kuvvetli asit & --- & --- \\
\hline & $4.5-5.5$ & Orta asit & --- & --- \\
\hline & $5.5-6.5$ & Hafif asit & --- & --- \\
\hline & $6.5-7.5$ & Nötr & 30 & 100.0 \\
\hline & $7.5-8.5$ & Hafif alkali & --- & --- \\
\hline & $>8.5$ & Kuvvetli alkali & --- & --- \\
\hline \multirow{4}{*}{$\begin{array}{l}\mathrm{EC}\left(\mathrm{dS} \mathrm{m} \mathrm{m}^{-1}\right) \\
\text { (Richards, 1954) }\end{array}$} & $0-4$ & Tuzsuz & 30 & 100.0 \\
\hline & $4-8$ & Hafif tuzlu & --- & --- \\
\hline & $8-15$ & Orta derecede tuzlu & --- & --- \\
\hline & $>15$ & Çok fazla tuzlu & --- & --- \\
\hline \multirow{5}{*}{$\begin{array}{l}\mathrm{CaCO}_{3}(\%) \\
\text { (Ülgen ve Yurtsever, 1995) }\end{array}$} & $<1.0$ & Az kireçli & 18 & 60.0 \\
\hline & $1.0-5.0$ & Kireçli & 3 & 10.0 \\
\hline & $5.0-15.0$ & Orta kireçli & 9 & 30.0 \\
\hline & $15.0-25.0$ & Fazla kireçli & --- & --- \\
\hline & $>25.0$ & Çok fazla kireçli & --- & --- \\
\hline \multirow{5}{*}{$\begin{array}{l}\text { Organik madde (\%) } \\
\text { (Ülgen ve Yurtsever, 1995) }\end{array}$} & $<1.0$ & Çok az & --- & --- \\
\hline & $1.0-2.0$ & $\mathrm{Az}$ & --- & --- \\
\hline & 2.0-3.0 & Orta & 1 & 3.3 \\
\hline & $3.0-4.0$ & İyi & 7 & 23.3 \\
\hline & $>4.0$ & Yüksek & 22 & 73.4 \\
\hline \multirow{5}{*}{$\begin{array}{l}\text { Alınabilir P (ppm) } \\
\text { (Olsen ve Sommers, 1982) }\end{array}$} & $<2.5$ & Çok az & 30 & 100.0 \\
\hline & $2.5-8$ & $\mathrm{Az}$ & --- & -- \\
\hline & $8-25$ & Yeterli & --- & --- \\
\hline & $25-80$ & Fazla & --- & --- \\
\hline & $>80$ & Çok fazla & --- & --- \\
\hline \multirow{6}{*}{$\begin{array}{l}\text { Alınabilir K (ppm) } \\
\text { (Pizer, 1967) }\end{array}$} & $<100$ & Çok düşük & --- & --- \\
\hline & $100-150$ & Düşük & --- & --- \\
\hline & $150-200$ & Orta & --- & --- \\
\hline & $200-250$ & İyi & 1 & 3.3 \\
\hline & $250-320$ & Yüksek & 3 & 10.0 \\
\hline & $>320$ & Çok yüksek & 26 & 86.7 \\
\hline \multirow{4}{*}{$\begin{array}{l}\text { Alınabilir Ca (ppm) } \\
\text { (Loue, 1968) }\end{array}$} & $<714$ & Çok fakir & --- & --- \\
\hline & $714-1430$ & Fakir & --- & --- \\
\hline & $1430-2860$ & Orta & --- & --- \\
\hline & $>2860$ & İyi & 30 & 100.0 \\
\hline \multirow{3}{*}{$\begin{array}{l}\text { Alınabilir Mg (ppm) } \\
\text { (Loue, 1968) }\end{array}$} & $<54$ & Fakir & --- & --- \\
\hline & $54-115$ & Orta & --- & --- \\
\hline & $>115$ & İyi & 30 & 100.0 \\
\hline
\end{tabular}

4. Kireç $\left(\mathrm{CaCO}_{3}\right):$ Kırkgeçit Köyü merası topraklarının kireç içeriği $\%$ 0.1-14.8 arasında değişmekte olup (Çizelge 1); yapılan sınıflandırmada, mera topraklarının \% 60.0'ının az kireçli, \% 10.0'ının kireçli ve \% 30.0'ının ise orta kireçli sınıfinda yer aldığı belirlenmiştir (Çizelge 2). Bolat (2007) Bartın'da yapmış olduğu çalışmasında, mera alanına ait toprakların kireç içeriğinin ortalama \% 2.44 olduğunu 
ve bu toprakların az kireçli topraklar sınıfına girdiğini bildirmiştir. Kılıç (2013) gerek kuzey bakılı meranın gerekse güney bakılı mera topraklarının az kireçli olduğunu; bununla birlikte, güney bakılı mera topraklarının kuzey bakılı mera topraklarına göre biraz daha fazla kireçli olduğunu tespit etmiştir. Literatürdeki bu sonuçlar araştırmamız bulgularını destekler niteliktedir. Ülke meralarında yapılan birçok çalışmalarda (Uslu, 2005; Şengönül ve ark., 2009; Ağın ve Kökten, 2013; Çaçan ve Kökten, 2014; Taşdemir, 2015) toprakların kireç içeriğinin yetersiz olduğu rapor edilmiştir.

5. Organik madde: İncelenen mera topraklarının organik madde kapsamları yöneylere göre \% 2.7612.45 arasında değişmektedir (Çizelge 1). Organik madde içerikleri yönünden toprakların büyük çoğunluğunun iyi ve yüksek düzeyde olduğu anlaşılmaktadır (Çizelge 2). Toprak organik maddesi, toprakta yetişen bitkiler ile toprak içinde yaşayan canlıların artıklarından oluştuğu (Okur, 2010) dikkate alındığında, mera topraklarının organik madde içeriklerinin yüksek olması; toprak işlemesinin söz konusu olmadığı bu alanlarda, bitki örtülerinin farklı özellikteki çok türü içeren karışımlardan oluşması, mevcut otların artıkları ve merada otlayan hayvanların dışkılarının toprakta ayrışması ve dolayısıyla meraların daha fazla organik madde oluşturmaları ile açıklanabilir.

Toprağın organik madde kapsamının yeterli düzeyde bulunması toprağın fiziksel, kimyasal ve biyolojik özelliklerini iyileştireceğinden toprak kalitesini de artırmaktadır. Organik madde, gözenekliliği ve toprakların su tutma kapasitesini artırır, yüzey akış kayıplarını azaltır (Chenu ve ark., 2000; Marinari ve ark., 2000). Kırkgeçit Köyü merasının killi bünyeli olduğu dikkate alındığında, toprak organik maddesinin yüksek olması, bu tip topraklarda havalanmanın düzenlenmesi açısından büyük önem taşımaktadır.

Artvin'in Ardanuç ilçesi Aydın Köyü meralarında yapılan çalışmada, mera alanındaki ortalama organik madde \% 5.01 olarak tespit edilmiştir (Bilgin, 2010). Erzurum Palandöken dağında farklı rakıma (I. kesim: 2000 m, II. kesim: 2500 m, III. kesim: 3000 m) sahip üç farklı mera alanında yapılan bir çalışmada ise, toprakların organik madde içerikleri mera kesimleri sirasina göre $\% \quad 2.30, \quad \% \quad 4.10, \quad \% \quad 6.84$ olarak belirlenmiştir (Çomaklı ve ark., 2012).

Uslu (2005), Kahramanmaraş Türkoğlu ilçesi Araplar Köyü Yeniyapan merası topraklarının; Ağın ve Kökten (2013), Bingöl Yedisu ilçesi Karapolat Köyü merası topraklarının; Çaçan ve Kökten (2014), Bingöl ili Merkez ilçesi Çiçekyayla Köyü merası topraklarının ve Taşdemir (2015), Elazı̆̆ ili Karakoçan ilçesi Bahçecik Köyü merası topraklarının orta düzeyde; Türker (2006), Mersin-Tarsus Olukkayak Köyü Topak Ardıç mevkii merası topraklarının organik maddece zengin; Babalık ve Sarıkaya (2015), Isparta ili Sütçüler ilçesi sınırları içerisinde yer alan, 1280 metre ortalama yükseltiye ve $\% \quad 5$ eğime sahip Zengi merası topraklarının ise organik madde miktarının iyi seviyede (\% 3.76) olduğunu bildirmektedirler.

6. Topraklarin makro besin maddesi ( $P, K, C a$ ve Mg) kapsamı: İncelenen mera topraklarının alınabilir P, $\mathrm{K}$, Ca ve $\mathrm{Mg}$ içeriklerinin mera geneli itibariyle sirasiyla; 0.011-0.097, 213-1092, 4352-12194 ve 1551153 ppm arasında değişiklik göstermiştir (Çizelge 1). Yapılan sinıflandırmada, incelenen mera topraklarının tamamının çok az düzeyde alınabilir P; iyi-çok yüksek düzeyde $\mathrm{K}$ ve iyi düzeyde alınabilir $\mathrm{Ca}$ ve $\mathrm{Mg}$ içerdiği belirlenmiştir (Çizelge 2). Bu sonuçlar, farklı ekolojilerde yapılan çalışmalarla (Türker, 2006; Çomaklı ve ark., 2012; Ăğn ve Kökten, 2013; Özaslan Parlak ve ark., 2015; Taşdemir, 2015) benzerlik gösterdiği görülmüştür.

Türkiye topraklarında yaygın olarak eksikliği en çok hissedilen makro besin elementlerinden olan fosfor; mera vejetasyonlarında, bitki kompozisyonu üzerinde etkili olmaktadır. Toprakta $\mathrm{P}$ eksikliği görülmeyen alanlarda zaman içerisinde, fosfora diğer bitkilerden daha çok ihtiyaç duyan baklagillerin oranı artar (Altın ve ark., 2005). Nitekim, çalışmanın yürütüldüğü Kırkgeçit Köyü merasında ağırlığa göre botanik kompozisyonda baklagillerin oranının mera yöneylerinin ortalaması olarak \% 7.61 olması (Yıldız ve Özyazıcı, 2017), mera topraklarının alınabilir fosfor içeriğinin yetersiz düzeyde bulunmasının da etkili olduğu düşünülmektedir.

Mera Kuru Otunun Makro Besin Maddesi (P, K,

\section{Ca ve Mg) Kapsamı}

Hayvanların temel besin maddesi kaynağı olan kaba yemlerin, yeterli kalitede olabilmesi için bünyelerinin yeterli miktarda besin maddesi kompozisyonuna sahip olması gerekmektedir. Çalışılan merada üretilen kaba yemin yöneylere göre; P oranı \% $0.22-0.28, \mathrm{~K}$ oran1 \% 2.35-2.70, Ca oran $1 \%$ 0.86-1.23, Mg oran1 \% 0.20-0.22 ve $\mathrm{K} / \mathrm{Ca}+\mathrm{Mg}$ oranı ise 1.89-2.61 arasında değişiklik göstermiştir. Mera otunun $\mathrm{P}$ ve $\mathrm{Ca}$ oranı, yöneyler arasında istatistiki açıdan sırasıyla $p<0.01$ ve $p<0.05$ düzeyinde önemli farklılık göstermiştir (Çizelge 3 ).

Çizelge 3. Mera kuru otunda belirlenen toplam P, K, Ca ve Mg değerleri (\%)

\begin{tabular}{lccccc}
\hline & $\mathrm{P}^{* *}$ & $\mathrm{~K}$ & $\mathrm{Ca}^{*}$ & $\mathrm{Mg}$ & $\mathrm{K} / \mathrm{Ca}+\mathrm{Mg}$ \\
\hline Kuzey & $0.28 \mathrm{a}$ & 2.70 & $0.93 \mathrm{ab}$ & 0.20 & 2.50 \\
Güney & $0.22 \mathrm{c}$ & 2.48 & $1.23 \mathrm{a}$ & 0.22 & 1.89 \\
Batı & $0.25 \mathrm{~b}$ & 2.35 & $0.86 \mathrm{~b}$ & 0.20 & 2.61 \\
\hline Ortalama & 0.25 & 2.51 & 1.00 & 0.21 & 2.33 \\
\hline
\end{tabular}

* $\mathrm{P}<0.05,{ }^{* *}: \mathrm{P}<0.01$ düzeyinde önemli

Bakoğlu ve ark. (1999) Erzurum yöresi çayır ve meralarında yürüttükleri araştırmalarında, botanik kompozisyonu oluşturan türlerin ortalaması olarak \% $1.00 \mathrm{Ca}$ ve $\% 3.85 \mathrm{~K}$ içerdiklerini bildirmektedirler. 
Doğal bir merada yürütülen bir başka çalışmada ise (Ayan ve ark., 2006), türlerin P içeriğinin \% 0.17-0.49, $\mathrm{K}$ içeriğinin \% 0.97-3.69, Ca içeriğinin \% $0.45-2.79$, $\mathrm{Mg}$ içeriğinin \% 0.01-1.19 ve $\mathrm{K} / \mathrm{Ca}+\mathrm{Mg}$ oranının ise 0.36-4.73 arasında değiştiği bildirilmiştir. Acar ve ark. (2009), Samsun ilinde doğal mera alanlarından topladıkları buğdaygil familyasına ait bitkilerin bazı kimyasal özelliklerini belirlemek amaciyla yürüttükleri çalışmada, türlerin; $\mathrm{P}, \mathrm{K}, \mathrm{Ca}, \mathrm{Mg}, \mathrm{K} /(\mathrm{Ca}+\mathrm{Mg})$ oranlarının sirasiyla, \% 0.01-0.30, \% 0.76-3.03, \% 0.08 $0.79, \% 0.06-0.17$ ve 3.05-7.36 arasında olduğunu tespit etmişlerdir. Kırkgeçit Köyü merasından elde edilen otun, adı geçen makro elementler yönünden kimyasal bileşiminin literatür bulgularıyla uyumlu olduğunu söylemek mümkündür.

Mera kuru otunun besin maddesi konsantrasyonları incelendiğinde, Muller (2009) tarafindan rasyonda olması gereken miktarlar (P için \% 0.40, $\mathrm{K}$ için \% 1.0, $\mathrm{Ca}$ için \% 0.90) dikkate alındığında; araştırmamızda elde edilen mera otunun $\mathrm{P}$ oranının bildirilen sınır değerin altında, $\mathrm{K}$ oranının yüksek, $\mathrm{Ca}$ oranının ise genel ortalamaya göre yeterli düzeyde olduğu görülmektedir (Çizelge 3). Çizelge 2'den de görüleceği üzere, mera topraklarının bitkiler tarafindan alınabilir $\mathrm{K}$ içeriğinin yeterli, Ca içeriğinin de iyi düzeyde olması, K ve $\mathrm{Ca}$ açısından mera bitkilerinin beslenme probleminin olmadığını söylemek mümkündür.

Incelenen meradan elde edilen kuru otların $\mathrm{P}$ içeriklerinin düşük düzeyde olmasında, araştırmanın yürütüldüğü meraların toprak özellikleri ve vejetasyon yapısının etkili olduğu düşünülmektedir. Nitekim, incelenen mera topraklarında bitkiler tarafindan alınabilir P miktarının çok az düzeyde olması (Çizelge 2), diğer toprak özelliklerinin etkisi ile birlikte, bitkiler tarafından $\mathrm{P}$ alımının yetersiz düzeyde gerçekleşmesine neden olmuştur. Araştırmanın vejetasyon etütlerinde de, ağırlığa göre botanik kompozisyonda baklagillerin düşük oranda (\% 7.61) yer alması (Yıldız ve Özyazıcı, 2017) da, bu sonucu desteklemektedir.

Mera kuru otunda belirlenen $\mathrm{Mg}$ oranları, Anonymous (2001)'un büyükbaş hayvan rasyonları için tavsiye ettiği değerinden (\% $\left.\begin{array}{l}\% \text { 0.25}\end{array}\right)$ düşük olduğu belirlenmiştir. Bitkiler genellikle kalsiyuma göre daha az $\mathrm{Mg}$; baklagil bitkileri, baklagil olmayan bitkilere göre daha fazla $\mathrm{Mg}$ içerir (Kacar ve İnal, 2008); dolayısıyla, Mg oranının düşük olmasında, vejetasyonda baklagil oranının düşüklüğünün etkili olduğu düşünülmektedir. Nitekim, buğdaygiller familyasına ait bitkilerin oransal olarak fazla olduğu kesimlerde (kuzey ve batı) (Yıldız ve Özyazıcı, 2017) Mg oranının düşüklüğü (Çizelge 3) dikkati çekmektedir.

Meraların $\mathrm{K} / \mathrm{Ca}+\mathrm{Mg}$ oranı ilkbaharda meralarda otlayacak hayvanlarda görülebilecek mera tetanisi için önemlidir. Meralarda tetani sınırı olan 2.2'nin üzerinde $\mathrm{K} /(\mathrm{Ca}+\mathrm{Mg})$ oranı, meranın kuzey ve batı kesiminde belirlenmiştir (Çizelge 3). K/(Ca+Mg) oranı yönünden mera geneli dikkate alındığında, otlayan hayvanların tetani ile karşı karşıya kalma riski bulunabileceği söylenebilir. $\mathrm{K} /(\mathrm{Ca}+\mathrm{Mg})$ oranı ile tetani hastalığı ilişkisi, Şahinoğlu (2010) ve Gür (2014) tarafindan da rapor edilmiştir.

\section{SONUC}

Mera alanlarından dengeli ve kaliteli kaba yem üretilebilmesi için, toprakların verimlilik düzeylerinin işlenebilir tarım arazilerinde olduğu gibi yeterli düzeyde olması gerekir. Araştırmada incelenen mera topraklarında, kireç ve bitkiler tarafından alınabilir $\mathrm{P}$ miktarının düşüklüğü göz önüne alındığında, mera topraklarının adı geçen besin maddeleri yönünden iyileştirilmesi büyük önem taşımaktadır. Bu amaçla, özellikle mera 1slah çalışmalarında gübreleme programlarına, kireçlemenin ve eksikliği görülen bitki besin maddelerinin dâhil edilmesi önerilmektedir.

\section{TEŞEKKÜR}

Bu çalışma, Siirt Üniversitesi (SİÜ), Fen Bilimleri Enstitüsü Yüksek Lisans Tez çalışmasının bir bölümünden üretilmiş olup; SİÜ Bilimsel Araştırma Projeleri Koordinatörlüğü tarafindan 2015-Sï̈FEB-38 no'lu proje ile desteklenmiştir.

\section{KAYNAKLAR}

Ağın Ö, Kökten K 2013. Bingöl İli Yedisu İlçesi Karapolat Köyü Merasının Botanik Kompozisyonunun Belirlenmesi. Türk Doğa ve Fen Dergisi, 2(1): 41-45.

Acar Z, Ayan İ, Önal Aşcı Ö, Başaran U, Mut H 2009. Biodiversity in Morphological Properties and Nutritional Values of Forage Grass Species. Journal of Environmental Biology, 30(4): 583-589.

Altın M, Gökkuş A, Koç A 2005. Çayır Mera Islahı. T.C. Tarım ve Köy İşleri Bakanlığı, Tarımsal Üretim ve Geliştirme Genel Müdürlüğü, Mart Matbaası, İstanbul, 468s.

Anonim 2017. Temel İstatistikler, Tarım Alanları. Türkiye İstatistik Kurumu, http://www.tuik.gov.tr/UstMenu.do?metod=temelist (Erişim tarihi: 25.06.2017).

Anonymous 1951. Soil Survey Manuel, Agricultural Research Administration U.S. Dept. of Agriculture Handbook. No.18, Gount Point Office Washington, p. 340-377.

Anonymous 1982. Methods of Soil Analysis-Part II. Chemical and Microbiological Properties, Agronomy Monograph No: 9: 323-336, ASA-SSSA, Wisconsin, USA.

Anonymous 1986. Methods of Soil Analysis-Part I. Physical and Mineralogical Properties, 2nd ed. ASA-SSSA, Agronomy Nomograph No: 9, Madison, WI.

Anonymous 2001. Nutrient Requirements of Dairy Cattle. Seventh Revised Edition. http://books.nap.edu/openbook.php?record_id=9825 \&page=110 (Erişim tarihi: 15.06.2017).

Avağ A 2002. Erzurum-Pasinler Yöresi Meralarının Bazı Toprak Özellikleri İle Mera Kalite Dereceleri Arasındaki İlişkiler. Atatürk Üniversitesi Fen 
Bilimleri Enstitüsü, Toprak Anabilim Dalı, Yüksek Lisans Tezi, Erzurum.

Ayan İ, Acar Z, Mut H, Başaran U, Önal Așcı Ö 2006. Morphological, Chemical and Nutritional Properties of Forage Plants in a Natural Rangeland in Turkey. Bangladesh J. Botany, 35(2): 133-142.

Ayan İ, Mut H, Acar Z, Başaran U, Töngel MÖ, Önal Aşçı Ö 2007. Samsun İli Kıyı Kesiminde Yer Alan Taban Meraların Bitki Örtüsü, Toprak Özellikleri ve Bazı Sorunlar. Türkiye VII. Tarla Bitkileri Kongresi, 25-27 Haziran, Erzurum.

Babalık AA, Sarıkaya H 2015. Isparta İli Zengi Merasinda Ot Verimi ve Botanik Kompozisyonun Tespiti Üzerine Bir Araştırma. Türkiye Ormancılık Dergisi, 16(2): 96-101.

Bakoğlu A, Koç A, Gökkuş A 1999. Erzurum Yöresi Çayır ve Mer'alarındaki Yaygın Bitki Türlerinin Ömür Uzunluğu, Çiçeklenmeye Başlama Tarihi ve Ot Kalitesi ile ilgili Bazı özellikleri. Tr. J. of Agriculture and Forestry, 23(Ek say1 4): 951-957.

Bilgin F 2010. Artvin Ardanuç-Aydın Köyü Yaylası Mera Vejetasyonu İle Bazı Toprak Özelliklerinin Yükseltiye Göre Değişiminin İrdelenmesi. Artvin Çoruh Üniversitesi Fen Bilimleri Enstitüsü, Yüksek Lisans Tezi, Artvin, 79s.

Bolat İ 2007. Farklı Arazi Kullanım Biçimlerinin Toprağın Mikrobiyal Biyokütle Karbon $\left(\mathrm{C}_{\text {mic }}\right)$ ve Azot $\left(\mathrm{N}_{\text {mic }}\right)$ İçeriğine Etkisi. Zonguldak Karaelmas Üniversitesi, Fen Bilimleri Enstitüsü, Orman Mühendisliği ABD, Yüksek Lisans Tezi, 104 s.

Chenu C, Le Bissonnais Y, Arrouays D 2000. Organic Matter Influence on Clay Wettability and Soil Aggregate Stability. Soil Sci. Soc. Am. J., 64: 14791486.

Çaçan E, Kökten K 2014. Bingöl İli Merkez İlçesi Çiçekyayla Köyü Merasının Ot Verimi ve Otlatma Kapasitesinin Belirlenmesi. Türk Tarım ve Doğa Bilimleri Dergisi, 2: 1727-1733.

Çomaklı B, Fayetörbay D, Daşçı M 2012. Changing of Botanical Composition and Canopy Coverage Ratio in Rangelands at Different Altitudes. Atatürk Üniversitesi Ziraat Fakültesi Dergisi, 43(1): 17-21.

Gökkuş A 2014. Kurak Alanlarda Yapay Mera Kurulması ve Yönetimi. Çanakkale Onsekiz Mart Üniversitesi Ziraat Fakültesi Dergisi, 2(2): 151-158.

Gökkuş A, Koç A 1996. Sürülen Meralarda Bitki Örtüsü Toprak İlişkisis. Tarım-Çevre İlişkileri Sempozyumu, 13-15 Mayis, Mersin.

Gür M 2014. Korunan, Otlanan ve Sürülüp Terk Edilen Doğal Meraların Bazı işlevleri ile Kimi Ekolojik Faktörler Arasındaki İlişkiler. Namık Kemal Üniversitesi, Fen Bilimleri Enstitüsü, Tarla Bitkileri Anabilim Dalı, Doktora Tezi, Tekirdağ, 137s.

Hoy MD, Moore KJ, George JR, Brummer EC 2002. Alfalfa Yield and Quality as Influenced by Establishment Metod. Agronomy Journal, 94(1): 6571.

Kacar B, İnal A 2008. Bitki Analizleri. Nobel Yayın No: 1241, Ankara, 892s.
Kılıç K 2013 Isparta Darıdere Havzası Meralarında Kuru Ot Verimi ve Botanik Kompozisyonun Belirlenmesi Üzerine Bir Araştırma. Süleyman Demirel Üniversitesi, Fen Bilimleri Enstitüsü, Orman Mühendisliği Anabilim Dalı, Yüksek Lisans Tezi, Isparta, 56s.

Larsen RJ, Marx ML 2001. An Introduction to Mathematical Statistics and Its Applications, Prentice Hall International, Inc. Upper Saddle River, New Jersey, USA, 768p.

Loue AT 1968. Diagnostic Petiolaire des Prospectian Etudes Sur la Nutrition at la Fertilization Potassiques de la Vigne. Societe Commerciale des Potasses d'Alsace. Services Agronomiques, 31-41.

Marinari S, Masciandar G, Ceccanti B, Grego S 2000. Influence of Organic and Mineral Fertilizers on Soil Biological and Physical Properties. Bioresource Technology, 72: 9-17.

Montgomery DC 2001. Design and Analysis of Experiments, Wiley, NY, 752p.

Muller LD 2009. Dietary Minerals For Dairy Cows on Pasture. (www.das.psu.edu/researchextension/dairy/.../pdf/mineralsforpasture.pdf.), Erişim tarihi: 25.05.2017).

Okur M 2010. Tarihsel Orta Anadolu Arazi Kullanım Dokusundaki Mera Bitkilerinin Toprak Kalitesine Etkileri. Çukurova Üniversitesi, Fen Bilimleri Enstitüsü, Arkeometri Anabilim Dalı, Yüksek Lisans Tezi, Adana, 140s.

Olsen SR, Sommers LE 1982. Phosphorus. Pp.539-579, In: Page, L.A., R.H. Miller and D.R. Keeney (Ed.), Methods of Soil Analysis, Part 2. Chemical and Microbiological Properties, Madison, Wisconsin, American Society of Agronomy.

Özaslan Parlak A, Parlak M, Gökkuş A, Demiray HC 2015. Akdeniz (Çanakkale) Meralarının Ot Verimi ve Kalitesi İle Botanik Kompozisyonu ve Bazı Toprak Özellikleri. Çanakkale Onsekiz Mart Üniversitesi Ziraat Fakültesi Dergisi, 3(1): 99-108.

Özyazıcı MA, Dengiz O, Aydoğan M, Bayraklı B, Kesim E, Urla Ö, Yıldız H, Ünal E 2016. Orta ve Doğu Karadeniz Bölgesi Tarım Topraklarının Temel Verimlilik Düzeyleri ve Alansal Dağılımları. Anadolu Tarım Bilimleri Dergisi, 31(1): 136-148.

Pizer NH 1967. Some Advisory Aspect. Soil Potassium and Magnesium. Tech. Bull. No.14: 184.

Richards LA 1954. Diagnosis and Improvement Saline and Alkaline Soils. U.S. Dep. Agr. Handbook 60.

Şahinoğlu O 2010. Bafra İlçesi Koşu Köyü Merasında Uygulanan Farklı Islah Yöntemlerinin Meranın Ot Verimi, Yem Kalitesi ve Botanik Kompozisyonu Üzerine Etkileri. Ondokuz Mayıs Üniversitesi, Fen Bilimleri Enstitüsü, Tarla Bitkileri ABD, Doktora Tezi, $136 \mathrm{~s}$.

Şengönül K, Kara Ö, Palta Ş, Şensoy H 2009. Bartın Uluyayla Yöresindeki Mera Vejetasyonunun Bazı Kantitatif Özelliklerinin Saptanması ve Ekolojik Yapının Belirlenmesi. Bartın Orman Fakültesi Dergisi, 11(16): 81-94. 
Taşdemir V 2015. Elazığ İli Karakoçan İlçesi Bahçecik Köyü Merasinda Verim ve Botanik Kompozisyonunun Saptanması Üzerine Bir Çalışma. Bingöl Üniversitesi, Fen Bilimleri Enstitüsü, Tarla Bitkileri ABD, Yüksek Lisans Tezi, $121 \mathrm{~s}$.

Türker AH 2006. Mersin-Tarsus Oluk Koyak Köyü Topak Ardıç Mevkisinde 1997 Yılından Beri Korunmuş Ağaçlandırma Sahasındaki Otsu Vejetasyonun Özellikleri Üzerine Bir Araştırma. ÇÜ., Fen Bilimleri Enstitüsü, Tarla Bitkileri ABD, Yüksek Lisans Tezi, $89 \mathrm{~s}$.

Uslu SÖ 2005. Kahramanmaraş İli Türkoğlu İlçesi Araplar Köyü Yeniyapan Merasında Botanik Kompozisyonun Tespiti ve Farklı Gübre Uygulamalarının Meranın Verim ve Botanik Kompozisyonuna Etkileri Üzerinde Araştırmalar. Çukurova Üniversitesi, Fen Bilimleri Enstitüsü,
Tarla Bitkileri Anabilim Dalı, Doktora Tezi, Adana, 162 s.

Ülgen N, Yurtsever N 1995. Türkiye Gübre ve Gübreleme Rehberi (4. Baskı). T.C. Başbakanlık Köy Hizmetleri Genel Müdürlüğü Toprak ve Gübre Araştırma Enstitüsü Müdürlüğü Yayınları, Genel Yayın No: 209, Teknik Yayınlar No: T.66, Ankara, 230s.

Yavuz T, Sürmen M, Töngel MÖ, Avağ A, Özaydın AK, Yildız H 2012. Amasya Mera Vejetasyonlarının Bazı Özellikleri. Tarım Bilimleri Araştırma Dergisi, 5(1): 181-185.

Yıldız A, Özyazıcı MA 2017. Karasal İklim Kuşağında Bulunan Bir Meranın Farklı Yöneylerinde Botanik Kompozisyonun, Ot Verimi ve Ot Kalitesinin Belirlenmesi. Türkiye Tarımsal Araştırmalar Dergisi, 4(3): 218-231. 